\title{
Wireless Capsule pH Monitoring: Does It Fulfil All Expectations?
}

\author{
Philippe Maerten $^{a} \quad$ Marianne Ortner ${ }^{a, b}$ Pierre Michetti ${ }^{a, b} \quad$ Gian Dorta ${ }^{a, b}$ \\ a Department of Gastroenterology and Hepatology, Centre Hospitalier Universitaire Vaudois, and \\ bUniversity of Lausanne, Lausanne, Switzerland
}

\section{Key Words}

$\mathrm{pH}$ monitoring $\cdot$ Wireless $\mathrm{pH}$ monitoring $\cdot$ Wireless capsule $\cdot$ Bravo capsule

\begin{abstract}
$\mathrm{pH}$ monitoring has been used as a diagnostic tool in gastrooesophageal reflux disease (GERD) for many years. Recent studies have shown that wireless capsule $\mathrm{pH}$ monitoring is better tolerated and interferes less with daily activities as compared to traditional catheter-based $\mathrm{pH}$ monitoring. Moreover, prolonged recording time ( $48 \mathrm{~h}$ instead of $24 \mathrm{~h}$ ) is possible with wireless $\mathrm{pH}$ monitoring. The main secondary effect of wireless capsule $\mathrm{pH}$ monitoring is induction of thoracic discomfort in $10-65 \%$ of the patients, which can vary from mild foreign body sensation to severe chest pain. Sensitivity and specificity of wireless capsule monitoring is comparable to that of traditional $\mathrm{pH}$ monitoring. It has not been proven yet that better tolerability and a longer recording time increases the diagnostic yield of wireless capsule monitoring in GERD.

Copyright $\odot 2007$ S. Karger AG, Basel
\end{abstract}

\section{Introduction}

The main indication for $\mathrm{pH}$ monitoring is in patients with persistent typical or atypical symptoms of gastrooesophageal reflux disease (GERD) under acid-suppressive therapy. The inconveniency of traditional ambulatory 24-hour $\mathrm{pH}$ monitoring is, however, the need of a naso-oesophageal catheter which is generally not well tolerated, and results in a changed lifestyle during $\mathrm{pH}$ monitoring. In 2003, the Bravo capsule (Medtronic, Minneapolis, Minn., USA) was introduced to overcome the inconveniencies of traditional $\mathrm{pH}$ monitoring. With this system a radiotelemetry $\mathrm{pH}$ capsule is attached to the mucosal wall of the oesophagus. It simultaneously measures $\mathrm{pH}$ and transmits data to a pager-sized receiver clipped onto the patients' belt, thereby circumventing the need for a nasally placed oesophageal catheter. Moreover, with the capsule, data recording during $48 \mathrm{~h}$ (or even longer) is possible.

We review the technical aspects of Bravo wireless $\mathrm{pH}$ monitoring, as well as the available studies on its tolerance and diagnostic value compared to traditional $\mathrm{pH}$ monitoring and combined multichannel intraluminal impedance (MII) and $\mathrm{pH}$ monitoring (MII pH monitoring).

\section{KARGER}

Fax +4161306 1234 E-Mail karger@karger.ch www.karger.com (c) 2007 S. Karger AG, Basel

0012-2823/07/0764-0235\$23.50/0

Accessible online at:

www.karger.com/dig
Philippe Maerten

Department of Gastroenterology-Hepatology

46, rue du Bugnon, $\mathrm{CH}-1010$ Lausanne (Switzerland)

Tel. +41 2131460 80, Fax +41213140707

E-Mail philippe.maerten@chuv.ch 

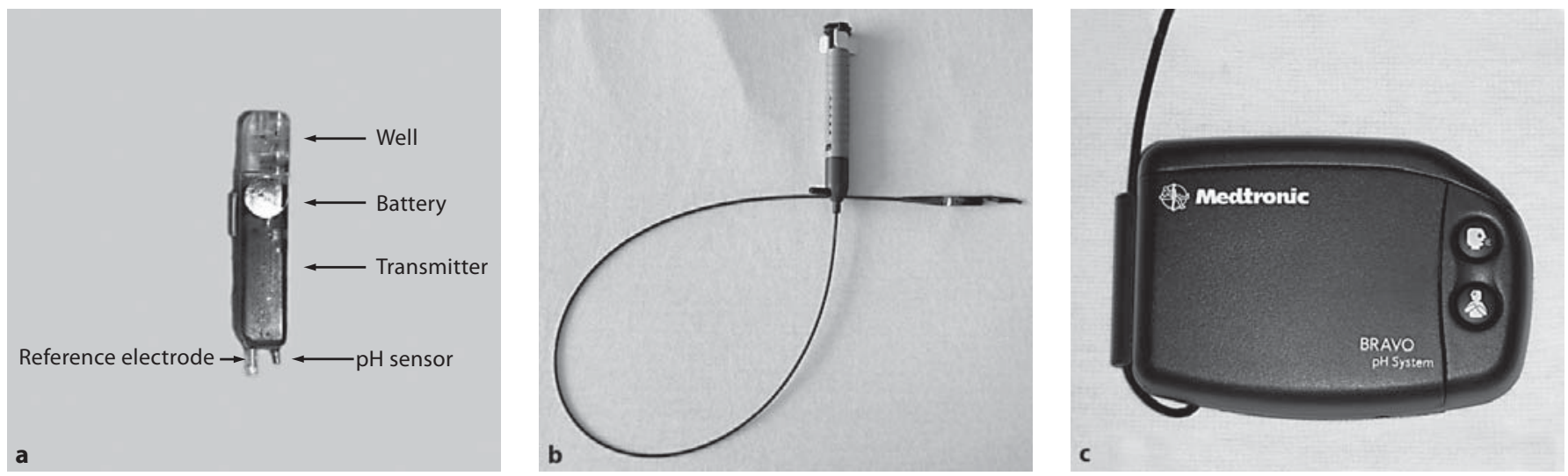

Fig. 1. a The Bravo capsule which is $6 \times 5.5 \times 25 \mathrm{~mm}$ has an antimony $\mathrm{pH}$ electrode and reference electrode located on its distal tip. It further contains an internal battery, a transmitter and a well. b Delivery system designed to place and attach the capsule in the oesophagus. It can be placed transnasal or transoral. c The receiver collects data emitted by the capsule by radiofrequency telemetry.

\section{Placement and Positioning of the Bravo Capsule}

The Bravo capsule measures $25 \times 6 \times 5.5 \mathrm{~mm}$ and has both an antimony $\mathrm{pH}$ and a reference electrode located on its distal tip. It further contains an internal battery, a transmitter and a mechanism to fix the capsule (fig. 1a).

After activation and calibration by submersion in $\mathrm{pH}$ buffer solutions of $\mathrm{pH} 7.0$ and $\mathrm{pH} 1.68$, the capsule is placed with a delivery system through the nose or mouth in the oesophagus (fig. 1b). The distal end of the capsule is placed $6 \mathrm{~cm}$ above the squamocolumnar junction (SCJ) (see below), determined during a previously performed gastroduodenoscopy. Next, a vacuum pump is connected to the delivery system which results in suction of the oesophageal wall into a well located in the upper part of the capsule. Negative pressure is maintained during 30-60 s, before an activation button activates a spring-loaded, stainless steel pin to be driven through the well of the $\mathrm{pH}$ capsule that attaches the $\mathrm{pH}$ capsule to the oesophageal wall. $\mathrm{pH}$ is recorded every $6 \mathrm{~s}$, and data are sent every $12 \mathrm{~s}$ to the external receiver by radiofrequency telemetry (fig. 1c). As for traditional $\mathrm{pH}$ monitoring, the recorder (provided of event markers for heartburn, chest pain and other symptoms) is attached to the belt of the patient. Bravo $\mathrm{pH}$ monitoring is more expensive than traditional $\mathrm{pH}$ monitoring or combined MII $\mathrm{pH}$ monitoring, due to a single-use capsule rather than a reusable catheter-based $\mathrm{pH}$ probe. In Switzerland for example, the price of the single-use capsule and delivery system is EUR 245.
Contraindications for the use of the Bravo capsule are hemorrhagic diathesis, oesophageal varices, severe oesophagitis, oesophageal strictures or diverticle, patients with a pacemaker or defibrillator and pregnancy. If magnetic resonance imaging is necessary within 1 month after placement of the Bravo capsule, an X-ray study is necessary to be sure that the capsule has been expulsed.

Traditional $\mathrm{pH}$ monitoring is performed $5 \mathrm{~cm}$ above the upper margin of the lower oesophageal sphincter (LES). This convention of position was selected to ensure that the electrode was distant enough from the stomach to minimize the potential for inadvertently becoming repositioned within the stomach in the course of the study (swallow-related movement, confounding effects of hiatus hernia, etc.) and yet close enough to the stomach to sample the region of oesophageal mucosal most adversely affected by gastro-oesophageal reflux [1]. Since the SCJ is located 1-1.5 cm below the LES [2], it has been proposed to place the Bravo capsule $6 \mathrm{~cm}$ above the SCJ, localised during a previous oesophago-gastroduodenoscopy [3]. The correctness of this approach has nicely been shown by Pandolfino et al. [4]. During endoscopy in healthy volunteers, the SCJ was localised, its distance to the incisors was noted and a stainless steel clip was fixed at this level. Then, the position of the LES was determined by manometry. The following day, a Bravo capsule was placed $6 \mathrm{~cm}$ above the SCJ and a traditional $\mathrm{pH}$ catheter was placed $5 \mathrm{~cm}$ above the proximal margin of the LES. Subsequently, the position of both electrodes was compared by fluoroscopy. Results showed that there was no difference in mean distance between the SCJ and either 
$\mathrm{pH}$ electrode, or between the proximal margin of the LES and either $\mathrm{pH}$ electrode. Moreover inter-subject variability for the position of the capsule was smaller than the inter-subject variability for the position of the catheter tip.

\section{Feasibility and Tolerability of Wireless Capsule pH Monitoring}

A major inconvenience of traditional $\mathrm{pH}$ monitoring is its limited tolerability, due to the presence of a nasooesophageal catheter during monitoring. Wireless $\mathrm{pH}$ monitoring is supposed to improve the comfort of the patient during the test by avoiding the need of a naso-oesophageal catheter. Several studies have reported on the tolerability of wireless $\mathrm{pH}$ monitoring.

In a well-designed study, Wong et al. [5] directly compared wireless capsule to traditional $\mathrm{pH}$ monitoring in a randomised trial including 50 patients referred for $\mathrm{pH}$ monitoring. The Bravo capsule was placed transnasally or, when this failed, transorally. Patients were instructed to report their symptoms, activities, diet, habits, sleep, adverse events, and lifestyle changes during the $\mathrm{pH}$ test, as well as overall experience of the test. Adverse effects were significantly less frequent during wireless capsule $\mathrm{pH}$ monitoring as compared to traditional $\mathrm{pH}$ monitoring, except for chest discomfort, which was significantly more frequent. Interference with daily activities, eating and sleep was significantly less during capsule $\mathrm{pH}$ monitoring as compared to traditional $\mathrm{pH}$ monitoring. $\mathrm{Pa}$ tients in the wireless $\mathrm{pH}$ capsule group were significantly less bothered by the test and rated their overall satisfaction higher than those randomised to traditional $\mathrm{pH}$ monitoring. Four domains of the SF-36 questionnaire (physical functioning, role limitation because of physical problems, social functioning and role limitation because of emotional problems) were significantly better in patients with the wireless capsule compared to traditional $\mathrm{pH}$ monitoring [5]. Several other studies have shown that wireless $\mathrm{pH}$ monitoring is well tolerated and interferes less with diet, activity, daily routine and sleep compared to traditional $\mathrm{pH}$ monitoring $[3,6,7]$.

Chest pain has been constantly observed with the Bravo system. Overall, it has been reported in $10.5-65 \%$ of patients [3, 5, 8-10]. Chest pain ranged from a sensation of foreign body, to severe chest pain requiring the ablation of the capsule immediately after [3], or exceptionally during the test $[9,11]$. The capsule can be removed using a cold snare placed loosely around the attachment base of the capsule on the oesophageal wall, followed by gentle traction. If not successful, the snare can be closed [12, 13].

In order to elucidate the pathogenesis of chest pain induced by the Bravo capsule, Tharavej et al. [10] compared manometry readings obtained before or after placement of a Bravo capsule. Chest pain was also recorded. They found that mean distal oesophageal contraction amplitudes were significantly higher in patients with the Bravo capsule in place as compared to those patients who had no capsule in the oesophagus. Moreover, $33 \%$ of patients in the study group had distal oesophageal contraction amplitudes exceeding the 95th percentile of normal, as compared with $10 \%$ in the control group. All 6 patients with hypertensive contractions reported new-onset chest pain, while only 4 of 14 patients reported chest pain in the absence of hypertensive contractions. From these data, the authors concluded that the Bravo capsule induces contraction abnormalities like oesophageal spasms, known to be associated with chest pain.

A case of oesophageal perforation occurred during placement of the Bravo capsule, associated with the delivery system [14].

The recording efficacy of wireless $\mathrm{pH}$ monitoring over $48 \mathrm{~h}$ has been reported in several studies now. Overall, sufficient hours of $\mathrm{pH}$ recording to be diagnostic are obtained in more than $95 \%$ of the performed examinations $[6,7]$. The most frequent reason of monitoring failure is premature capsule detachment, followed by prolonged periods of no data recording.

\section{Bravo pH Monitoring Is Accurate to Detect GERD}

The question whether wireless capsule monitoring is accurate to detect GERD has now been addressed in several studies. Moreover, studies directly comparing wireless and traditional $\mathrm{pH}$ monitoring have been performed.

In 2003, Pandolfino et al. [3] published the first full paper on wireless capsule $\mathrm{pH}$ monitoring. 41 patients with GERD symptoms ( 25 with confirmed oesophagitis and 16 with normal upper endoscopy) and 44 asymptomatic controls underwent ambulatory wireless capsule $\mathrm{pH}$ monitoring during $48 \mathrm{~h}$. Sensitivity and specificity to diagnose pathologic reflux over $48 \mathrm{~h}$ with the wireless capsule (median total time of $\mathrm{pH}<4$ ) were comparable to those reported in studies on traditional $\mathrm{pH}$ monitoring [15-17]. Although data from the first and second day were comparable for each group, 12 out of 37 GERD pa- 
tients as well as 7 out of 39 asymptomatic controls had pathologic reflux (defined as more than $5.3 \%$ of total time of $\mathrm{pH}<4$, which was the 95th percentile in the asymptomatic controls over $48 \mathrm{~h}$ ) on one but not the other day of recording, an observation also reported by others $[6$, 18]. In view of these observations, the authors next analysed $\mathrm{pH}$ data from the worst day only. By doing so, sensitivity to diagnose pathologic reflux in GERD patients with endoscopically proven oesophagitis enhanced from 78 to $100 \%$ with some loss in specificity however (decrease from 95 to $85 \%$ ). These data have, however, to be interpreted with caution since diagnosis of pathologic reflux for the worst day was based on a cut-off from the asymptomatic group over $48 \mathrm{~h}$ but not from the worst day, which would have been higher.

It has been suggested that wireless $\mathrm{pH}$ monitoring performed at $1 \mathrm{~cm}$ instead of $6 \mathrm{~cm}$ above the SCJ could enhance sensitivity and specificity of wireless capsule $\mathrm{pH}$ monitoring compared to traditional $\mathrm{pH}$ monitoring [19]. However, a recent study by Bansal et al. [20] has shown that wireless $\mathrm{pH}$ monitoring performed at $1 \mathrm{~cm}$ above the SCJ does not improve the sensitivity or specificity of wireless $\mathrm{pH}$ monitoring compared to monitoring performed at $6 \mathrm{~cm}$ above the SCJ.

In another study, des Varannes et al. [21] performed wireless capsule $\mathrm{pH}$ monitoring during $48 \mathrm{~h}$ and traditional $\mathrm{pH}$ monitoring (during the first $24 \mathrm{~h}$ ) in parallel in 40 patients with GERD. Surprisingly, the total time of $\mathrm{pH}$ $<4$ as well as the total number of reflux events reported by capsule $\mathrm{pH}$ monitoring were significantly lower as compared to traditional $\mathrm{pH}$ monitoring. Despite this, there was a strong and highly significant correlation between the 24-hour oesophageal acid exposure recorded by both recording systems. An $88 \%$ concordance between both recording systems to diagnose GERD was found when the cut-off of total time of $\mathrm{pH}<4$ for capsule $\mathrm{pH}$ monitoring calculated from the regression equation was used. Moreover, sensitivity to establish a relation between symptoms and reflux was comparable for both. Although these data show that wireless capsule $\mathrm{pH}$ monitoring is a good tool to diagnose GERD, they suggest that the system is less sensitive compared to traditional $\mathrm{pH}$ monitoring. However, in a similar study with healthy volunteers, Pandolfino et al. [4] were able to show that the difference in $\mathrm{pH}$ recording was due to an overestimation of acidity by traditional $\mathrm{pH}$ monitoring, due to a flaw in the software algorithm. Indeed, although they confirmed the observations from des Varannes et al. [21] that total time of $\mathrm{pH}$ $<4$ was significantly inferior with wireless capsule $\mathrm{pH}$ monitoring compared to traditional $\mathrm{pH}$ monitoring, they could elegantly show by using consumption of orange juice during $\mathrm{pH}$ monitoring as an internal control, that the $\mathrm{pH}$ recorded by the capsule was closer to that of the known $\mathrm{pH}$ of orange juice than did traditional $\mathrm{pH}$ monitoring. After manual correction for the error between the recorded and real $\mathrm{pH}$ for all data of the $\mathrm{pH}$ tracing, the apparent discrepancy in acid exposure time reported by the two systems disappeared. However, the number of reflux episodes reported by traditional $\mathrm{pH}$ monitoring remained significantly higher compared to the number reported by wireless capsule $\mathrm{pH}$ monitoring [22]. Pandolfino et al. [22] were able to show that this discrepancy was mainly due to differences in detection of short, but not long reflux events. Moreover, short reflux events accounted for only a minority of total acid exposition. They thus concluded that the enhanced number of reflux events reported by traditional $\mathrm{pH}$ monitoring had only minor clinical significance, if any - a conclusion also made by des Varannes et al. [21]. The difference in short reflux events may partly be due to the lower sampling frequency of wireless $\mathrm{pH}$ monitoring compared to traditional $\mathrm{pH}$ monitoring (every sixth and fourth second, respectively).

From these studies it is clear that the values used to define pathologic reflux in traditional $\mathrm{pH}$ monitoring may not be transposed to wireless capsule $\mathrm{pH}$ monitoring. Although Pandolfino et al. [3] determined 5.3\% of total time of $\mathrm{pH}<4$ as upper limit of normal (95th percentile), the group of healthy volunteers was poorly defined. The question of the upper limit of physiologic acid reflux, defined as the 95th percentile in asymptomatic controls, has been best answered in a study by Wenner et al. [7]. In this study, wireless capsule $\mathrm{pH}$ monitoring was performed in 50 asymptomatic volunteers, 25 men and 25 women evenly distributed within each gender, with a minimum of 2 subjects in each 5 -year age interval. In this study, the 95th percentile of percentage of total time of $\mathrm{pH}<4$ over $48 \mathrm{~h}$ was $4.4 \%$. The 95 th percentile of percentage of $\mathrm{pH}<4$ in upright position was $6.3 \%, 3.7 \%$ for supine position and $9.6 \%$ postprandial. The 95 th percentile for the number of reflux episodes over $48 \mathrm{~h}$ was 93 and for those lasting for more than $5 \mathrm{~min}$ this number was 5.

\section{Discussion}

Since the introduction of wireless capsule $\mathrm{pH}$ monitoring in 2003, several studies have clearly shown its feasibility and technical reliability in the diagnosis of GERD. 
Moreover, wireless capsule $\mathrm{pH}$ monitoring is better tolerated and interferes less with diet, activity, daily routine and sleep as compared to traditional $\mathrm{pH}$ monitoring. The main inconveniency of wireless capsule $\mathrm{pH}$ monitoring, however, is induction of thoracic discomfort (which can vary from mild foreign body sensation to severe chest pain) induced by the capsule attached to the oesophageal wall, and reported in $10-65 \%$ of the patients. It has been proposed that chest pain is related to disturbances in oesophageal motility, induced by the capsule [10]. Whether these motility disturbances influence the oesophageal $\mathrm{pH}$ is, however, not known.

Despite enhanced tolerance and recorded time, the expectation that this would improve sensitivity and specificity of wireless $\mathrm{pH}$ monitoring compared to traditional $\mathrm{pH}$ monitoring has not been achieved. It also remains to be proven whether using data from the worst day only enhances accuracy of wireless $\mathrm{pH}$ monitoring compared to traditional $\mathrm{pH}$ monitoring.

From the studies $[4,21]$ that performed traditional and wireless $\mathrm{pH}$ monitoring in parallel, it is also clear that data obtained with both recording systems cannot be compared to each other. Therefore, new reference values above which acid reflux is considered as pathologic are necessary for wireless $\mathrm{pH}$ monitoring. Based on available data, a cut-off at $4.4 \%$ of total time of $\mathrm{pH}<4$ over $48 \mathrm{~h}$ (which was the 95th percentile of percentage of total time of $\mathrm{pH}<4$ over $48 \mathrm{~h}$ in a study on 50 healthy volunteers, well balanced for age and sex [7]) offers at present the best basis for the routine use of wireless $\mathrm{pH}$ monitoring in the diagnosis of patients with GERD.

Finally, wireless $\mathrm{pH}$ monitoring will probably be challenged by combined MII $\mathrm{pH}$ monitoring in the future. This latter has the advantage to detect acid as well as weakly or non-acid reflux and enables exact assessment of the proximal extent of refluxed material [23]. For patients on acid-suppressive therapy, where isolated $\mathrm{pH}$ monitoring has a very low diagnostic yield, combined MII $\mathrm{pH}$ monitoring may show in a proportion of patients an association between symptoms of regurgitation, cough, chest pain or heartburn and non-acid reflux [24]. Wireless $\mathrm{pH}$ monitoring is therefore mainly useful in patients off acid-suppressive therapy to diagnose whether or not acid reflux accounts for patients symptoms. However, in this population, studies are warranted to compare sensitivity and specificity of wireless $\mathrm{pH}$ monitoring compared to combined MII pH monitoring. Indeed, Hila et al. [25] have recently shown that additional information of impedance on $\mathrm{pH}$ data eliminates false-positive interpretation of acid reflux into the oesophagus, thereby enhancing the specificity of $\mathrm{pH}$ monitoring compared to $\mathrm{pH}$ monitoring alone.

\section{References}

1 Kahrilas PJ, Quigley EM: Clinical esophageal $\mathrm{pH}$ recording: a technical review for practice guideline development. Gastroenterology 1996;110:1982-1996.

-2 Kahrilas PJ, Lin S, Chen J, Manka M: The effect of hiatus hernia on gastro-oesophageal junction pressure. Gut 1999;44:476-482.

-3 Pandolfino JE, Richter JE, Ours T, Guardino JM, Chapman J, Kahrilas PJ: Ambulatory esophageal $\mathrm{pH}$ monitoring using a wireless system. Am J Gastroenterol 2003;98:740749.

-4 Pandolfino JE, Schreiner MA, Lee TJ, Zhang Q, Boniquit C, Kahrilas PJ: Comparison of the Bravo wireless and digitrapper catheterbased $\mathrm{pH}$ monitoring systems for measuring esophageal acid exposure. Am J Gastroenterol 2005;100:1466-1476.

5 Wong WM, Bautista J, Dekel R, Malagon IB, Tuchinsky I, Green C, Dickman R, Esquivel R, Fass R: Feasibility and tolerability of transnasal/per-oral placement of the wireless $\mathrm{pH}$ capsule vs. traditional 24-hour oesophageal $\mathrm{pH}$ monitoring - a randomized trial. Aliment Pharmacol Ther 2005;21:155163.

Wireless Capsule pH Monitoring:

Does It Fulfil All Expectations?
6 Gillies RS, Stratford JM, Booth MI, Dehn TC: Oesophageal $\mathrm{pH}$ monitoring using the Bravo catheter-free radio capsule. Eur J Gastroenterol Hepatol 2007;19:57-63.

7 Wenner J, Johnsson F, Johansson J, Oberg S: Wireless oesophageal $\mathrm{pH}$ monitoring: feasibility, safety and normal values in healthy subjects. Scand J Gastroenterol 2005;40: 768-774.

8 Ahlawat SK, Novak DJ, Williams DC, Maher KA, Barton F, Benjamin SB: Day-to-day variability in acid reflux patterns using the Bravo $\mathrm{pH}$ monitoring system. J Clin Gastroenterol 2006;40:20-24.

$\checkmark 9$ Bhat YM, McGrath KM, Bielefeldt K: Wireless esophageal $\mathrm{pH}$ monitoring: new technique means new questions. J Clin Gastroenterol 2006;40:116-121.

10 Tharavej C, Hagen JA, Portale G, Hsieh CC, Gandamihardja TA, Lipham JC, Peters JH, DeMeester SR, Crookes PF, Bremner CG, DeMeester TR: Bravo capsule induction of esophageal hypercontractility and chest pain. Surg Endosc 2006;20:783-786.
-11 Triester SL, Leighton JA, Budavari AI, Crowell MD, Fleischer DE: Severe chest pain from an indwelling Bravo $\mathrm{pH}$ probe. Gastrointest Endosc 2005;61:317-319.

12 Pandolfino JE: Bravo capsule $\mathrm{pH}$ monitoring. Am J Gastroenterol 2005;100:8-10.

13 Prakash C, Jonnalagadda S, Azar R, Clouse RE: Endoscopic removal of the wireless $\mathrm{pH}$ monitoring capsule in patients with severe discomfort. Gastrointest Endosc 2006;64: 828-832.

14 Fajardo NR, Wise JL, Locke GR 3rd, Murray JA, Talley NJ: Esophageal perforation after placement of wireless Bravo $\mathrm{pH}$ probe. Gastrointest Endosc 2006;63:184-185.

-15 Masclee AA, de Best AC, de Graaf R, Cluysenaer OJ, Jansen JB: Ambulatory 24-hour $\mathrm{pH}$-metry in the diagnosis of gastroesophageal reflux disease. Determination of criteria and relation to endoscopy. Scand J Gastroenterol 1990;25:225-230.

16 Mattioli S, Pilotti V, Spangaro M, Grigioni WF, Zannoli R, Felice V, Conci A, Gozzetti G: Reliability of 24-hour home esophageal $\mathrm{pH}$ monitoring in diagnosis of gastroesophageal reflux. Dig Dis Sci 1989;34:71-78. 
-17 Vitale GC, Sadek S, Tulley FM, Rimmer AR, Hunter BE, Phelan J, Cuschieri A: Computerized 24-hour esophageal $\mathrm{pH}$ monitoring: a new ambulatory technique using radiotelemetry. J Lab Clin Med 1985;105:686-693.

- 18 Tseng D, Rizvi AZ, Fennerty MB, Jobe BA, Diggs BS, Sheppard BC, Gross SC, Swanstrom LL, White NB, Aye RW, Hunter JG: Fortyeight-hour $\mathrm{pH}$ monitoring increases sensitivity in detecting abnormal esophageal acid exposure. J Gastrointest Surg 2005;9:10431051.

-19 Pandolfino JE, Lee TJ, Schreiner MA, Zhang Q, Roth MP, Kahrilas PJ: Comparison of esophageal acid exposure at 1 and $6 \mathrm{~cm}$ above the squamocolumnar junction using the Bravo $\mathrm{pH}$ monitoring system. Dis Esophagus 2006;19:177-182.
20 Bansal A WS, Rastogi A, Hall S, Higbee AD, Sharma P: Utility of proximal versus distal $\mathrm{pH}$ monitoring for the diagnosis of GERD. Gastroenterology 2007;132:S1920.

21 Des Varannes SB, Mion F, Ducrotte P, Zerbib F, Denis P, Ponchon T, Thibault R, Galmiche JP: Simultaneous recordings of oesophageal acid exposure with conventional $\mathrm{pH}$ monitoring and a wireless system (Bravo). Gut 2005;54:1682-1686.

22 Pandolfino JE, Zhang Q, Schreiner MA, Ghosh S, Roth MP, Kahrilas PJ: Acid reflux event detection using the Bravo wireless versus the slimline catheter $\mathrm{pH}$ systems: Why are the numbers so different? Gut 2005;54: 1687-1692.
23 Sifrim D, Blondeau K: Technology insight: the role of impedance testing for esophageal disorders. Nat Clin Pract Gastroenterol Hepatol 2006;3:210-219.

24 Zerbib F, Roman S, Ropert A, des Varannes SB, Pouderoux P, Chaput U, Mion F, Verin E, Galmiche JP, Sifrim D: Esophageal pH-impedance monitoring and symptom analysis in GERD: a study in patients off and on therapy. Am J Gastroenterol 2006;101:19561963.

25 Hila A, Agrawal A, Castell DO: Combined multichannel intraluminal impedance and $\mathrm{pH}$ esophageal testing compared to $\mathrm{pH}$ alone for diagnosing both acid and weakly acidic gastroesophageal reflux. Clin Gastroenterol Hepatol 2007;5:172-177. 